\title{
O ZNACZENIU ŚWINY WE WCZESNYM ŚREDNIOWIECZU
}

\author{
THE SIGNIFICANCE OF THE ŚWINA STRAIT \\ IN THE EARLY MIDDLE AGES
}

\begin{abstract}
The article contains an analysis of archaeological and historical sources related to the Świna, one of three straits constituting the mouth of the Oder to the Baltic. By referring to the sources, an attempt was made to evaluate the ways of taking advantage of the strait and its significance in the early Middle Ages.
\end{abstract}

Keywords: early Middle Ages, Baltic region, the Oder, archaeology.

Rejon ujścia Odry od dawna zwracał uwagę badaczy wczesnego średniowiecza, zarówno historyków, jak i archeologów. Wynikało to chociażby z dość oczywistego spostrzeżenia, iż rzeka stanowiła najdogodniejsze w zachodniej części południowego wybrzeża Bałtyku wodne połączenie komunikacyjne z głębokim zapleczem lądowym. W rejonie ujścia Odry znajdowało się przesławne miasto Iumne, opisane przez Adama z Bremy (II, 23) i łączone z wielkim zespołem osadniczym rozpoznanym w Wolinie (np. Kiersnowski 1950, s. 36-39). Tam wreszcie lokalizowany jest na wpół legendarny Jomsborg (Morawiec 2009), a w nieco późniejszym okresie rozgrywały się główne militarne akordy zmagań duńsko-pomorskich (Eggert 1927) i rozwinęły się ważne centra polityczno-gospodarcze pomorskiego księstwa, takie jak Kamień, Szczecin, Uznam czy Wołogoszcz (zob. łącznie np. Bollnow 1964; Leciejewicz 1983).

Pod względem geograficznym zasadniczy element ujściowego odcinka rzeki stanowi Zalew Szczeciński, z którego wyjście na Bałtyk tworzą trzy długie i wąskie cieśniny: Piana, Świna i Dziwna, opływające dwie duże wyspy ulokowane w ujściu rzeki, czyli Uznam i Wolin. Znaczenie cieśnin we wczesnym średniowieczu było od dawna przedmiotem zainteresowania historiografii, zwłaszcza polskiej.

* Katedra Archeologii Uniwersytetu Szczecińskiego, ul. Krakowska 71-79, 71-017 Szczecin, e-mail: marian.rebkowski@univ.szczecin.pl. 
Problem poruszany był najczęściej przy okazji analizy szerszych zagadnień, a dotyczył takich kwestii jak: komunikacyjna rola cieśnin, ich wpływ na rozwój osadnictwa na przylegających do nich brzegach, a także domniemana funkcja graniczna jednej z nich. Pojawiały się również osobne studia, z których najważniejszym i podstawowym do dnia dzisiejszego pozostaje dzieło Władysława Kowalenki (1954). W swej rozprawie ten poznański historyk, analizując podstawowy zasób źródeł pisanych i kartograficznych, uwzględniał również wymowę dostępnych wówczas danych archeologicznych. Ponieważ od tamtego czasu istotnej zmianie uległ jednak stan rozpoznania geomorfologicznego i archeologicznego ujścia Odry, problem wymaga ponownego rozpatrzenia. W tym miejscu zajmiemy się zagadnieniem roli, jaką we wczesnośredniowiecznych dziejach ziem nadbałtyckich odegrała środkowa z trzech cieśnin, czyli Świna.

Świna, oddzielająca od siebie mierzejowo-morenowe wyspy Uznam i Wolin, stanowiła w przeszłości zdecydowanie najkrótsze połączenie Zalewu Szczecińskiego z Bałtykiem. Jej długość wynosi niespełna $20 \mathrm{~km}$, podczas gdy długości Piany i Dziwny są znacznie, nawet dwuipółkrotnie większe (Kowalenko 1954, s. 13 i n.; Gaziński 2006, s. 139) ${ }^{1}$. Przez Świnę przepływa aż około 60\% wód, jakie Zalew Szczeciński wymienia z morzem (Osadczuk 1999, s. 11), a jej głębokość waha się w granicach $2-5 \mathrm{~m}$. Obydwa brzegi cieśniny stanowią najniższe partie wysp Uznam i Wolin. Zbudowane są one z piaszczystych osadów akumulacji mierzejowo-deltowej. Teren ten pokrywają piaski, muły, torfowiska i moczarowe łąki (Malinowski 1973, s. 15; Osadczuk 1999, s. 91; Dudzińska-Nowak 2017, s. 222-224). Ten podmokły obszar, poprzecinany kanałami i rozlewiskami cieśniny, z licznymi wysepkami o bezwzględnych wysokościach terenu przewyższających poziom morza o zaledwie kilkadziesiąt centymetrów, tworzy tzw. Bramę Świny, mającą szerokość dochodzącą do kilkunastu kilometrów (Kondracki 1998, s. 48). Na znacznych jej partiach, wzdłuż brzegu morza i nierównomiernie na obu brzegach cieśniny, w tym terenowym obniżeniu osadziły się wały wydmowe, których wysokość osiąga nawet kilkanaście metrów nad poziom morza (Malinowski 1973, s. 12-14, ryc. 5). Dla poruszanej tu problematyki szczególnie istotne są wyniki analiz geomorfologicznych dowodzące, że najmłodsze $\mathrm{z}$ wydm tworzyły się stosunkowo niedawno, pomiędzy V a XVII w. n.e., a ich linie zmieniały się nawet $w$ ostatnich stuleciach (Piotrowski 1999, s. 15 i n., zwł. 22; Borówka i in. 2017, s. 211-212; Dudzińska-Nowaczyk 2017 s. 229 i n.). Oznacza to również, że zupełnie inaczej niż obecnie wyglądało pierwotne ujście Świny. W średniowieczu nie było ono tak jak teraz wysunięte w morze, lecz miało kształt lejka o szerokości dochodzącej do $200 \mathrm{~m}$. Linia brzegowa była zatem znacznie cofnięta, nawet o blisko dwa kilometry (Dworaczyk, Piotrowski 2011, s. 16, tab. I i II).

${ }^{1}$ W 2. połowie XIX w. drogę wodną z Bałtyku przez Świnę na Zalew Szczeciński jeszcze bardziej skróciło przekopanie kanału na płd.-wsch. skraju wyspy Uznam (tzw. Kaiserfahrt, dzisiejszy Kanał Piastowski). 


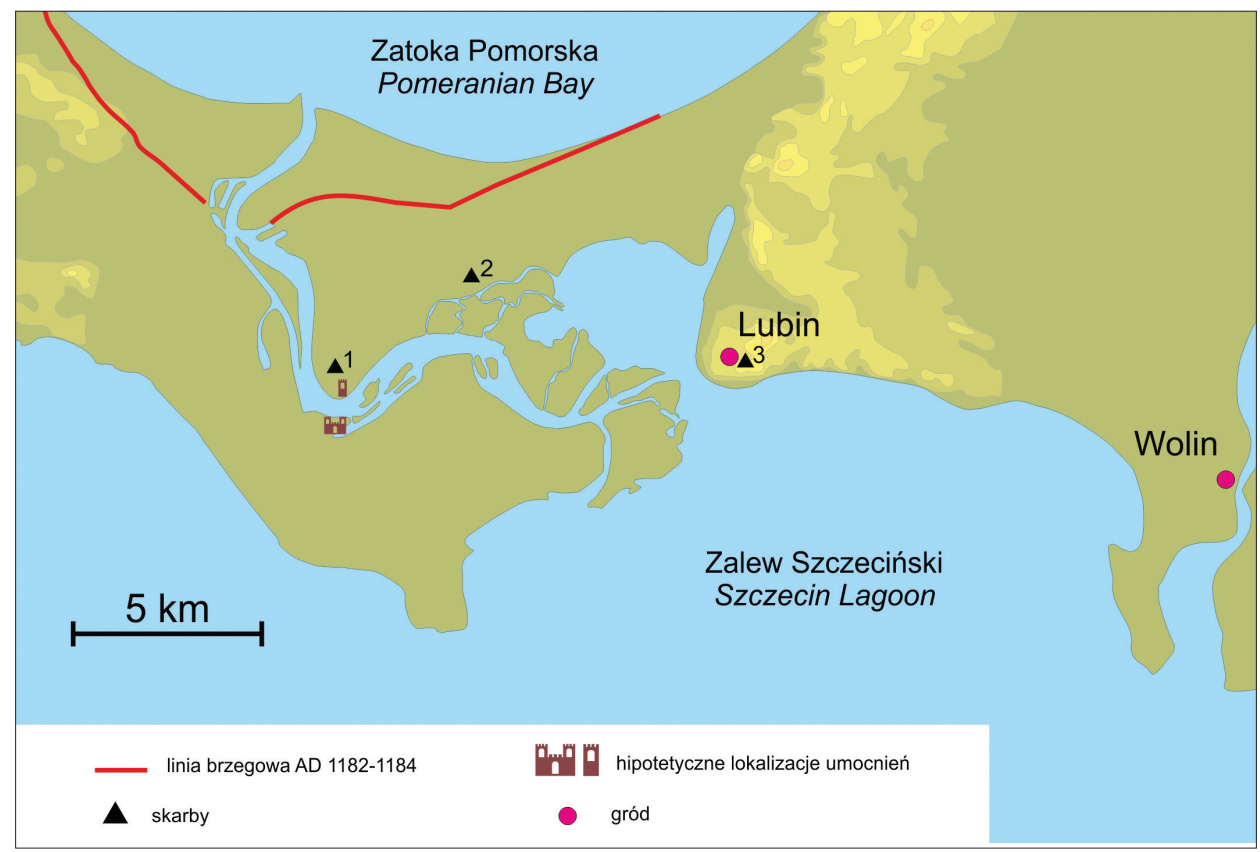

Ryc. 1. Brama Świny we wczesnym średniowieczu. Grafika: K. Zielińska

Dopiero w odległości kilku kilometrów na wschód i zachód od brzegów cieśniny zaczynają się wzniesienia morenowe zajmujące centralne partie obydwu wysp i osiągające wysokości kilkudziesięciu metrów nad poziom morza (Malinowski 1973, s. 12 i n.). Najbliższe z nich to tzw. Pagórki Lubińsko-Wapnickie, tworzące wał morenowy schodzący wysoką falezą do Zalewu Szczecińskiego w miejscu, gdzie zaczyna się kanał Świny (ryc. 1).

Zarysowane pokrótce, dość specyficzne warunki środowiska naturalnego jasno wskazują, że wzdłuż całego biegu cieśniny, w odległości kilku co najmniej kilometrów od jej brzegów brak dogodnych miejsc do stałego osadnictwa. Już w końcu XII w., w jednym z najstarszych przekazów źródłowych, w których pojawia się nazwa cieśniny (por. niżej), mowa o rozciągającym się przy niej pustkowiu (PUB I, nr 102²; por. Leciejewicz 1975). Okoliczność powyższa musiała mieć istotny wpływ na charakter wykorzystania tego połączenia wodnego w przeszłości. Biorąc pod uwagę ów brak dogodnych warunków osadniczych i stan ówczesnej wiedzy archeologicznej, W. Kowalenko dowodził przed laty, że Świna nie miała większego znaczenia komunikacyjnego we wczesnym średniowieczu, a jej rola wzrosła dopiero po lokacji Szczecina na prawie niemieckim w XIII w. (Kowalenko 1954, s. 58 i n.). Opinia ta stała w sprzeczności z wyrażanymi nieco wcześniej pogląda-

\footnotetext{
2 (...) totum desertum, quod extenditur a Zwina (...).
} 
mi innych badaczy, wedle których to właśnie Świna była we wczesnym średniowieczu główną drogą komunikacyjną i handlową w ujściowym odcinku szlaku odrzańskiego, a jej rola jeszcze wzrosła po zamuleniu Dziwny około połowy XII w. (Czaplewski 1947, s. 12 i n. ${ }^{3}$, Kiersnowski 1951, s. 188, 210; Sułowski 1952, s. 375-378). W ostatnim czasie wyrażono pogląd w jakimś stopniu pośredni, wskazujący, że dopiero od lat 80 . XII w. Świna zyskała znaczenie gospodarcze jako droga handlowa i utrzymała je aż do końca średniowiecza (Gaziński 2006, s. 141 i n.).

Próbując rozstrzygnąć zarysowany powyżej problem, przypomnijmy na wstępie, że nazwa cieśniny pojawiła się w źródłach pisanych dopiero w 2. połowie XII w., w dokumentach kancelarii książąt zachodniopomorskich (PUB I, nr 90, 1182 r. Szvvine; nr 102, 1186 lub 1187 r. - Zvina) oraz w opisach ówczesnych zmagań pomorsko-duńskich zanotowanych nieco tylko później w dziele Saxa Gramatyka (passim, Zuina, Zuyna).

Najstarsze we wczesnym średniowieczu ślady aktywności ludzkiej w Bramie Świny stanowią znaleziska monetarne (por. Wehner 2007, s. 51, Abb. 21), przede wszystkim dwa skarby odkryte jeszcze w XIX w. na prawym brzegu cieśniny, w Przytorze i Łężycy (ryc. 1)4. W pierwszym z nich, ukrytym po 975 r., znajdowały się liczne monety arabskie, niemieckie i duńskie oraz ozdoby, w tym charakterystyczne skandynawskie zapinki typu Terslev (Filipowiak 1962, s. 202-203; Bogucki $\mathrm{i}$ in. 2016, s. 541-542). W skład drugiego, dla którego terminus post quem ukrycia ustalono na 982 r. (lub 1024 r.), wchodziły ozdoby, dirhemy oraz monety niemieckie (Eggers 1978, s. 18-19; Filipowiak 1962, s. 145-146; Bogucki i in. 2016, s. 317-318). Nie można wykluczyć, że niektóre z pięciu (?) pojedynczych monet arabskich znalezionych luźno w okolicach Świnoujścia i Łężycy, ale także po drugiej stronie cieśniny w Karsiborze, mogły pochodzić z tych właśnie skarbów (Filipowiak 1962, s. 146, 203, 272-273; Kiersnowscy 1959, s. 56, 105; Bogucki i in. 2016, s. 283, przyp. 216). Nieco tylko starszy może być skarb monet arabskich ukryty na wysokim wyniesieniu morenowym w Lubinie, tuż u nasady Świny, po 951 r. (Kiersnowscy 1959, s. 61; Bogucki i in. 2016, s. 309-310). Chronologia ukrycia skarbów, przypadająca na 2. połowę X w. i ewentualnie pierwszą połowę następnego stulecia, dobrze odpowiada strukturze chronologicznej znalezisk monetarnych z pobliskiego emporium wolińskiego (Bogucki 2013) i w ogóle okresowi jego największego rozkwitu (zob. łącznie Filipowiak, Konopka 2008, s. 253 i n.).

Tylko niewiele wcześniej datowane są początki osadnictwa na dwóch sąsiadujących ze sobą wzniesieniach morenowych opadających wysokim klifem do Zalewu Szczecińskiego tuż u nasady ujścia Świny w Lubinie. Najstarsze ślady zasiedlenia w miejscu, gdzie później powstał gród, możemy datować najwcześniej na koniec IX w., a najprawdopodobniej dopiero na 1. połowę X stulecia. Z tym okresem zwią-

\footnotetext{
${ }^{3}$ Ksiądz Paweł Czaplewski nazywał w swym tekście Świnę Dźwiną.

${ }^{4}$ Pomijamy tu oczywiście skarb solidów bizantyńskich z przełomu V i VI w. odkryty nad Świną w Karsiborze (Ciołek 2003, s. 70-73), związany jeszcze ze schyłkiem starożytności na Pomorzu.
} 
zane są słabo zachowane warstwy kulturowe zarejestrowane w płn.-zach. części wzgórza, gdzie odkryto stosunkowo nieliczny zespół fragmentów naczyń częściowo obtaczanych na kole, głównie rodzin form D (Menkendorf) i C (Feldberg), a może także inne przedmioty odkryte na wtórnym złożu, takie jak fragment wagi szalkowej i klucz. Nie mamy pewności, jaki był charakter tej osady i czy już wówczas mogła na wzniesieniu istnieć jakaś forma umocnień (Rębkowski 2016, s. 63; Rębkowski, red. 2018 , s. 186, 372). W sferze hipotez musi też pozostać przypuszczenie, że w okresie jej funkcjonowania ukryto na wzgórzu wzmiankowany powyżej skarb dirhemów. Równie dobrze moment zdeponowania skarbu może wyznaczać dopiero kres istnienia osady. Na ten sam mniej więcej czas wolno datować osadę powstałą na wzniesieniu sąsiadującym ze wzgórzem grodowym od południowego wschodu. W trakcie ratowniczych badań wykopaliskowych przeprowadzonych tam w $1954 \mathrm{r}$. stwierdzono, że najstarszy poziom osadniczy wyznacza jama zawierająca wyłącznie ułamki naczyń częściowo obtaczanych na kole (Filipowiak 1959, s. 316).

W samej Bramie Świny, po obu stronach cieśniny brak jednoznacznych archeologicznych śladów osadnictwa, które mogłoby być datowane na wczesne średniowiecze (por. Łosiński 1982, s. 45-48, 149, ryc. 8 i 9; Herold 1995, s. 21-28, Abb. 2; Szczesiak 1995, s. 46-50). W literaturze przedmiotu pojawiały się w przeszłości domysły o istnieniu grodzisk w Karsiborze i Przytorze. W pierwszej z wymienionych miejscowości, która pojawia się po raz pierwszy w źródłach pisanych dopiero w XIII w. jako wioska, najpewniej rybacka (PUB I, nr 318), brak było jakichkolwiek podstaw do takiego domysłu. Negatywnie zweryfikowały go kilkukrotne prospekcje terenowe (Filipowiak 1962, s. 105; por. Dworaczyk, Piotrowski 2011, s. 13). W Przytorze natomiast miano w latach 30. XX w. odkryć fragmenty wczesnośredniowiecznych naczyń, nóż i osełkę oraz kamienie, wiązane z jakąś formą umocnień (Kunkel 1940, s. 336, przyp. 215), a miejscowość włączono do listy domniemanych grodzisk (Eggers 1978, s. 230; ostatnio Wehner 2007, s. 36, Abb. 10). Także jednak i tutaj domysły takie nie zostały potwierdzone przez powojenne weryfikacje terenowe (Filipowiak 1962, s. 203). Obiekt ten, jeśli w ogóle istniał, należałoby chyba jednak łączyć z umocnieniami zbudowanymi dopiero w 2. połowie XII w., w dobie wojen duńsko-pomorskich (por. niżej).

Oddzielny problem stanowi pytanie, czy Świna i bezludzie rozciągające się wzdłuż jej brzegów mogły mieć w tym okresie charakter graniczny. Wynika ono przede wszystkim ze znanego przekazu Adama z Bremy (II, 21 oraz II, 22) ${ }^{5}$, na podstawie którego można sądzić, że w połowie XI stulecia dolna Odra stanowiła granicę między plemionami wieleckimi a Pomorzanami. Nie brak było opinii ekstrapolujących tę informację na czasy wcześniejsze i uznających ujściowy odcinek rzeki także za granicę państwa wczesnopiastowskiego w końcu X w. (tak np. Sułowski 1952, s. 356-358). Trudno oczywiście rozstrzygnąć, czy autor kroniki kościoła hamburskiego, pisząc te słowa, miał konkretnie na myśli jedną z trzech

${ }^{5}$ Adam z Bremy II, 21: Oddara ... pertranseat usque ad Iumnen, ubi Pomeranos dividit a Wilzis. 
cieśnin łączących Zalew Szczeciński z Bałtykiem. Zdania badaczy są w tym zakresie podzielone: jedni sugerują, że granicą tą była Świna (np. Czaplewski 1947, s. 12; Sułowski 1952, s. 427), inni zaś, że Dziwna (np. Kowalenko 1954, s. 21-22; Labuda 1988, s. 66). Można jedynie zauważyć, że warunki terenowe raczej wskazywałyby na pierwszą z nich.

Zasadniczą zmianę $\mathrm{w}$ osadnictwie tych ziem stanowił moment budowy grodu u nasady ujścia cieśniny, na wysokim wyniesieniu terenowym w Lubinie. Na podstawie analizy struktur odkrytych ułamków naczyń glinianych, monety i chronologii młodszych nawarstwień budowę umocnień datować możemy na koniec XI w. lub przełom XI i XII stulecia (Rębkowski 2016, s. 63; Rębkowski red. 2018, s. 178, 373). Z pewnością umocnienia istniały już w 1124 r., skoro przy okazji wizyty bpa Ottona w tymże roku miejscowość określona została mianem castrum (por. niżej). Warto przy tym zwrócić uwagę na fakt, że w okresie, w którym wzniesiono gród lubiński, doszło także do ważnych zmian w osadnictwie grodowym wschodniego pobrzeża Zalewu Szczecińskiego. Wtedy to bowiem zniszczone zostały grody w Mścięcinie i Kamieniu. Pierwszy z nich, położony na zachodnim brzegu Odry opodal jej ujścia do Zalewu Szczecińskiego, przestał funkcjonować najpóźniej na przełomie XI i XII w., a jego kres wyznacza skarb monet zdeponowany około 1100 r. (Rogosz 1974, s. 30-31, 71, 77; Kiersnowscy 1959, s. 73; Bogucki i in. 2016, s. 521). Podobnie ma się rzecz z grodem kamieńskim, usytuowanym w rejonie ujścia Dziwny. Obiekt został spalony gdzieś na przełomie XI i XII w., a terminus post quem wydarzenia wyznacza najprawdopodobniej skarb monet ukryty po 1080 r. (Filipowiak 1962, s. 92; 1997, s. 260-261; Bogucki i in. 2016, s. 271-275). Jak można przypuszczać, wszystkie te wydarzenia mogły mieć związek z ekspansją na zachód i próbą przejęcia kontroli nad ujściem Odry przez zachodniopomorskich książąt, których siedzibę w tym czasie tradycyjnie lokalizuje się w leżącym ponad $100 \mathrm{~km}$ na wschód Kołobrzegu (tak już Quandt 1868, s. 152 i niemal cała późniejsza historiografia, np. Leciejewicz 1962, 269-271; Spors 1981, s. 214; por. Piskorski 2002, s. 68-70). Gród kamieński, w przeciwieństwie do obiektu w Mścięcinie, został szybko odbudowany i jeszcze przed pierwszą misją biskupa Ottona w 1124 r. stał się główną siedzibą książęcą (Kiersnowski 1951, s. 11-182; Bollnow 1964, s. 170-178; Spors 1981, s. 214).

Jak wolno zatem przypuszczać, na początku XII w. Świna mogła przez krótki czas stanowić zachodnią granicę władztwa Warcisława, aż do czasu ekspansji na ziemie wieleckie w latach 20. XII w. (Spors 1988, s. 73 i n., 201 i n.).

W ciągu 1. połowy XII w. w Lubinie rozrósł się w zespół osadniczy, na który oprócz grodu składało się kilka osad i cmentarz (Rębkowski red. 2018, s. 21, 373-375). Jedna z rozpoznanych osad wzmiankowana była nieco tylko później jako vicus ante castrum (PUB I, nr 102; Filipowiak 1962, s. 141), co może wskazywać na jej gospodarcze znaczenie. Pojawiające się także wówczas informacje o jazach na Świnie i przekazanie prawa połowu ryb w Lubinie klasztorowi benedyktynów ze Stołpia nad Pianą (PUB I, nr 88; nr 102; PUB VII, nr 4628) wskazuje na istotną, 
gospodarczą rolę rybołówstwa. Potwierdzeniem demograficznego i politycznego znaczenia ośrodka było skierowanie tam w 1124 r. misji chrystianizacyjnej prowadzonej na Pomorzu przez biskupa Ottona z Bambergu (Hofmeister 1924, s. 16; Rosik 2010, s. 302). Zwraca przy tym uwagę sposób, w jakim autorzy żywotów misjonarza w swych relacjach z wyprawy opisywali miejscowość. Herbord (II, 37) zdaje się podkreślać jej militarne znaczenie, określając Lubin mianem grodu (castellum $^{6}$, natomiast Mnich z Prüfening (VP II, 14) zwracał z kolei uwagę na jego inne cechy, nazywając miasteczkiem (civitatula) ${ }^{7}$. Takie zróżnicowanie perspektywy dość dobrze jednak oddawało rzeczywistość społeczno-gospodarczą i ówczesny charakter Lubina, który stał się policentrycznym zespołem osadniczym. Jego skala była jednak mniejsza niż rozległych zespołów osadniczych tego typu, takich jak np. Kołobrzeg, Szczecin czy nieodległy Uznam, a ze względu na położenie pierwszorzędne znaczenie miały jego funkcje militarne, a z czasem też administracyjne. W ciągu XII stulecia Lubin stał się głównym grodem prowincji, obejmującej swym zasięgiem całą zachodnią część wyspy Wolin (Ślaski 1960, s. 85-87; Spors 1988, s. 97-98; 1991, s. 60-61). Tym samym podtrzymana została graniczna rola Świny; teraz już jednak cieśnina stanowiła granicę administracyjną w księstwie zachodniopomorskim: okręgu grodowego (prowincji) i kasztelanii ${ }^{8}$.

Dla właściwej oceny struktur osadniczych istniejących w rejonie Świny w młodszych fazach wczesnego średniowiecza wypada w tym miejscu ustosunkować się pokrótce również do kwestii istnienia grodu na zachód od biegu cieśniny, na wyspie Uznam. Ten historiograficzny problem związany jest z próbami lokalizacji w tym rejonie grodu Gradicia (Gridiz), wzmiankowanego wraz z Lubinem w przywoływanych powyżej przekazach z żywotów św. Ottona (zob. wyżej, przyp. 5 i 6). Wprawdzie większość badaczy zgodna jest raczej co do lokalizowania jej na południe od Szczecina, w dzisiejszym Gartz nad Odrą, to jednak nie brak było również pomysłów łączących obiekt z miejscowością Garz, położoną na wschodnim skraju wzniesień morenowych wyspy Uznam, w odległości kilku kilometrów na zachód od brzegu Świny (zob. łącznie Rymar 1992 oraz Rosik 2010, s. 301-303). $\mathrm{Na}$ podstawie toponimii domyślano się tam od dawna istnienia grodziska (Kunkel 1932, s. 91, a za nim Eggers 1978, s. 228), chociaż nigdy nie udało się takiego

${ }^{6}$ Episcopus autem tenorem pacti quo ab eis recesserat mente habens, cogitabat quidem statim post conversionem Stetinae ad eos properare; sed rogatus est duo prius invisere castella, Gradiciam videlicet et Lubinum; quae in confinio posita ad pagum pertinebant Stetinensem. At ubi hominus illi, velut arida inbrem sitiens, verba evangelii suscipientes, fidei sacramentis imbuti sunt, extructo altari et sanctificato per castellum utrumque, atque ordinatis illic sacerdotibus, per Odoram flumen in mare lapsi, vento meliori ad Iulinae litora navigavimus.

${ }^{7}$ Iam vero omnibus in fide Domini confortatis beatus pontifex ad civitatulam quandam Gridiz dictam per Oderam navigio venit indeque rursus ad aliam in littore maris sitam, qua Liubin dicitur, navigavit et pluribus utrubique cinversis Stetinenses reinvisere maturavit.

${ }^{8}$ Pomijamy w tym miejscu pojawiającą się w cytowanych publikacjach dyskusję na temat, czy prowincja lubińska wchodziła w skład kasztelanii wolińskiej, czy szczecińskiej, przychylając się do pierwszej z wyrażanych opinii. Dla poruszanych tutaj kwestii zagadnienie nie ma większego znaczenia. 
obiektu zidentyfikować w terenie. Rozpoznano tam tylko ślady osadnictwa datowanego na młodsze fazy wczesnego średniowiecza (Corpus 1979, s. 185; Herold 1995, s. 37). Grodziska nie zlokalizowano również na nieodległym wzniesieniu Golm, w rejonie którego miałaby w późnym średniowieczu istnieć wieś nosząca nazwę Gardis (Holtz 1958, s. 28-29; Ślaski 1960, s. 77).

Nowy etap w dziejach wykorzystania Świny jako drogi komunikacyjnej rozpoczął się w dobie najazdów duńskich na Pomorze. Prowadzone od lat 60. XII w. przez Waldemara I, a następnie przez jego syna Kanuta VI, miały one charakter wypraw morskich, których drogi w głąb Pomorza wiodły przez cieśniny prowadzące do Zalewu Szczecińskiego (Eggert 1927; 1928). Początkowo odbywały się Pianą, a następnie, od 1170 r. - Świną (Eggert 1928, s. 45 ff.; Kowalenko 1954, s. 18, 83; Bollow 1964, 46-53). Co charakterystyczne, nigdy flota duńska nie wpłynęła na Pomorze przez Dziwnę. Wedle powszechnie akceptowanej opinii badaczy było to następstwem ówczesnego zapiaszczenia tej cieśniny, czego dowodem są opisane przez Saxa Gramatyka (XIV, 42; por. Eggert 1928, s. 45 i n.; Myśliński 1948, s. 26-27), nieudane próby wydostania się tą drogą na Bałtyk okrętów dowodzonych przez biskupa Absalona w trakcie najazdu Waldemara datowanego na 1170 rok $^{9}$.

Kilka lat później, w 1173 lub 1176 r. Waldemar I dotarł ze swoją wyprawą aż do Szczecina, a w drodze powrotnej zdobył Lubin (Eggert 1927, s. 58-59, 95, 145; 1928, s. 56; Guzikowski 2016, s. 96-97). Relacjonujący te wydarzenia Saxo Gramatyk (XIV, 43,5) opisuje je dość lakonicznie ${ }^{10}$. Trudno jednak wątpić, że zdobycie grodu było jednoznaczne $\mathrm{z}$ jego zniszczeniem.

Nie jest zapewne dziełem przypadku, że na lata 60.-80. XII w., a więc okres wypraw duńskich, datowana jest przebudowa umocnień grodu w Lubinie (Rębkowski red. 2018, s. 179, 376). Nie dysponując bardziej precyzyjnymi wyznacznikami chronologicznymi, nie jesteśmy jednak w stanie stwierdzić, czy to przedsięwzięcie podjęto wskutek zniszczeń dokonanych w czasie najazdu z 1173 (1176) r., czy też jeszcze przed nim, celem podniesienia walorów obronnych grodu wobec częstego pojawiania się floty duńskiej w ujściu Odry. Można jednak zauważyć, że zarówno relikty starszego wału grodowego, którego powstanie datujemy gdzieś na przełom XI i XII, jak i wału młodszego noszą ślady gwałtownych pożarów. Zniszczenie jednego $\mathrm{z}$ nich należy zatem najprawdopodobniej łączyć ze zdobyciem Lubina przez Duńczyków. Sekwencja wydarzeń z lat 70. i 80. XII w. pozwala raczej skłaniać się ku przyjęciu twierdzenia, że w czasie najazdu z 1173 r. (1176 r.) zniszczony został wał młodszy, co w konsekwencji - jak zobaczymy poniżej stanowiło $\mathrm{w}$ istocie kres istnienia lubińskiego grodu.

9 Nie sposób dzisiaj precyzyjnie określić momentu, w którym Dziwna straciła we wczesnym średniowieczu swoją żeglowność. Co więcej, ostatnie badania zdają się potwierdzać starsze domysły na temat jej zupełnie odmiennego przebiegu w odcinku ujściowym, co najprawdopodobniej w przyszłości spowoduje konieczność rewizji wielu przyjmowanych za pewniki ustaleń historiografii dotyczących osadnictwa wczesnośredniowiecznego u ujścia Odry.

${ }^{10}$ Post haec navigationem remensi, capto Lyubino, Rugiam revehuntur. 
W nieco późniejszym dokumencie księcia Bogusława I z 1186 lub 1187 r. (PUB I, 102), na mocy którego gród lubiński wraz z całym okręgiem grodowym przekazany został prepozytowi kapituły kamieńskiej, znajduje się informacja mówiąca o tym, że już wcześniej jego brat, Kazimierz, ofiarował ten gród istniejącemu w Lubinie kościołowi św. Mikołaja. Ponieważ Kazimierz objął we władanie swoją dzielnicę około 1160 r., a zginął w 1180 r. (Rymar 2005, s. 119), na te lata datować należy tę donację. Wydaje się niemal pewne, że stało się to po zniszczeniu grodu lubińskiego przed Duńczyków, czyli gdzieś w latach 1173(1176)-1180.

Za konsekwencję zniszczenia grodu w Lubinie, który nie został odbudowany, należy najprawdopodobniej uznać akcję budowy przez pomorskich władców w latach 1177-1182 innych umocnień u ujścia Świny do Baltyku (Eggert 1927, s. 142-143; 1928, s. 57; Kiersnowski 1951, s. 210; Kowalenko 1954, s. 58), a więc w podmokłym terenie, niesprzyjającym stałemu osadnictwu. Pierwsze z umocnień zostało zalane przez morze wkrótce po wzniesieniu (Saxo XV, 6). Zbudowane w jego miejsce dwa inne zdobyły wojska duńskie już w 1184 r. (Saxo XVI, 6). Przeprowadzona niedawno analiza powyższych przekazów, geomorfologii ujściowego odcinka cieśniny i rozpoznania archeologicznego pozwoliła wskazać dwie możliwe lokalizacje tych inwestycji, które najpewniej znajdowały się w przewężeniu koryta Świny, kilka kilometrów na zachód od Lubina (ryc. 1; por. Dworaczyk, Piotrowski 2011, s. 16-17, tablica I). Już w rok po zdobyciu tych umocnień, w 1185 r., flota duńska po raz kolejny przebyła Świnę, a wyprawa zakończyła się złożeniem przez księcia pomorskiego Bogusława I hołdu lennego duńskiemu władcy Kanutowi VI w Kamieniu (Saxo XVI, 8; Myśliński 1948, s. 40-41). Z punktu widzenia poruszanych $\mathrm{w}$ tym miejscu kwestii oznaczało to zaprzestanie najazdów duńskich i utratę przez Świnę jej strategicznego znaczenia. W późniejszym okresie, w XIII-XIV w., Świna stanie się ważnym szlakiem handlowym łączącym nadodrzańskie miasta lokacyjne z Bałtykiem (Gaziński 2006, s. 141-145).

\section{WNIOSKI}

Próbując zrekapitulować problem roli, jaką odgrywała we wczesnym średniowieczu Świna, zacząć wypada od ponownego podkreślenia specyficznych warunków środowiska naturalnego istniejących po obu jej brzegach, całkowicie odmiennych od tych panujących wzdłuż pozostałych cieśnin łączących Zalew Szczeciński z Bałtykiem. Powodowały one, że bezpośrednio nad Świną nie mogły ukształtować się trwałe struktury osadnicze, a najbliższym dogodnym miejscem dla takich celów były wzniesienia w Lubinie, położone u nasady ujścia cieśniny. Znaleziska skarbów i monet dowodzą jednak, że najpóźniej od około połowy X w. cieśnina stała się ważną drogą komunikacyjną. Jak można przypuszczać, miało to bezpośredni związek z okresem rozkwitu emporium wolińskiego. Nie można wykluczać, że pustkowie rozciągające się wówczas wzdłuż cieśniny stanowiło rubież międzyplemienną. 
Rola Świny uległa zmianie w okresie załamania się dalekosiężnego handlu bałtyckiego w XI w., a zwłaszcza po opanowaniu ujścia Odry przez książąt zachodniopomorskich. Wzniesienie grodu w Lubinie na przełomie XI i XII w. dobitnie podkreślało strategiczny charakter cieśniny. Obiekt ułatwiał kontrolę nad wodnym szlakiem komunikacyjnym prowadzącym w głąb lądu, ale będącym najpewniej także jedynym szlakiem wiodącym z Bałtyku do Wolina, jeśli przyjęlibyśmy, że już tego czasu sięgają problemy ze spławnością Dziwny. Przypomnieć w tym miejscu wypada, że Wolin ostatecznie znalazł się pod kontrolą księcia dopiero w końcu lat 20. XII w. (Leciejewicz 1962, s. 277-279).

Pierwszorzędne strategiczne znaczenie Świny, a tym samym grodu lubińskiego, ujawniło się dobitnie w dobie najazdów duńskich, kiedy to począwszy od 1170 r., ta właśnie cieśnina stała się główną drogą wiodącą w kierunku Szczecina, Wolina i głównej siedziby książęcej w Kamieniu. Próby utrzymania przez pomorskich władców kontroli nad Świną przez budowę kolejnych umocnień na jej brzegach, podjęte na przełomie lat 70. i 80. XII w. po uprzednim zniszczeniu przez Duńczyków grodu lubińskiego, spełzły na niczym; Świną wpłynęła na Zalew Szczeciński flota duńska w trakcie wyprawy z 1185 r., która doprowadziła do uzależnienia księstwa pomorskiego od Danii. Od tego czasu cieśnina stanowiła jedynie dogodną drogę handlową, której znaczenie jeszcze wzrosło w okresie ożywienia gospodarczego w dobie lokacji miast.

\section{BIBLIOGRAFIA}

\section{Źródła}

Adam z Bremy - Magistri Adam Bremensis Gesta Hammaburgensis ecclesiae pontificum, Scriptores rerum Germanicarum in usum scholarum ex Monumentis Germaniae Historicis separatu editi, wyd. B. Schmeidler, Hannover-Lipsk 1917.

Ebo - Ebonis Vita S. Ottonis episcopi Babenbergensis, MPH, series nova, t. 7, fasc. 2, wyd. J. Wikarjak, K. Liman, Warszawa 1969.

Herbord - Herbordi Dialogus de Vita S. Ottonis episcopi Bebenbergensis, MPH, series nova, t. 7, fasc. 3, wyd. J. Wikarjak, K. Liman, Warszawa 1974.

Saxo Gramatyk - Saxonis Gesta Danorum, wyd. J. Olrik, H. Raeder, Huniae 1931.

PUB - Pommersches Urkundenbuch, t. 1 (2. Aufl.), wyd. K. Conrad, Köln-Wien 1970; t. 7, 2. Lieferung, wyd. H. Friederichs, Stettin 1936.

VP - S. Ottonis episcopi Babenbergensis Vita Prieflingensis, MPH, series nova, t. 7 fasc. 1, wyd. J. Wikarjak, K. Liman, Warszawa 1966. Tłumaczenie polskie: Żywot z Prüfening Ottona biskupa bamberskiego, thum. J. Wikarjak, w: Pomorze Zachodnie w żywotach Ottona, Warszawa 1979, s. 45-137.

\section{Literatura}

Bogucki M. 2013, Coin Finds from Wolin and its Hinterland, w: M. Bogucki, M. Rębkowski (red.), Economies, Monetisation and Society in the West Slavic Lands 800-1200 AD, Wolińskie Spotkania Mediewistyczne, t. 2, Szczecin, s. 345-357. 
Bogucki M., Ilisch P., Suchodolski S. (red.) 2016, Frühmittelalterliche Münzfunde aus Polen. Inventar II, Pommern, Warszawa.

Bollnow H. 1964, Studien zur Geschichte der pommerschen Burgen und Städte im 12. und 13. Jahrhundert, Köln-Graz.

Borówka R., Osadczuk A., Osadczuk K., Witkowski A., Skowronek A., Latałowa M., Mianowicz K. 2017, Postglacial Evolution of the Odra River Mouth, Poland-Germany, w: J. Harff, K. Furmańczyk, H. von Storch (red.), Coastline Changes of the Baltic Sea from South to East. Past and Futire Projection, Cham, s. 193-217.

Ciołek R. 2003, Znaleziska solidów na Pomorzu, „Wiadomości Numizmatyczne” 47/2(176), s. 163-180.

Czaplewski P. 1947, Studia nad regestem Dagome iudex. Zapiski Towarzystwa Naukowego w Toruniu 12, 1946, s. 3-45.

Dudzińska-Nowak J. 2017, Morphodynamic Processes of the Swina Gate Coastal Zone Development (Southern Baltic Sea), w: J. Harff, K. Furmańczyk, H. von Storch (red.), Coastline Changes of the Baltic Sea from South to East. Past and Futire Projection, Cham, s. 219-255.

Dworaczyk M., Piotrowski A. 2011, Próba lokalizacji wczesnośredniowiecznych grodzisk u ujścia Świny $w$ świetle analizy morfostratygraficznej wałów wydmowo-mierzejowych, w: M. Rębkowski (red.), Ekskluzywne życie - dostojny pochówek. W kręgu kultury elitarnej wieków średnich, Wolińskie Spotkania Mediewistyczne, t. 1, Wolin, s. 13-20.

Eggers H.J. 1978, Funde der wendisch-wikingischen Zeit in Pommern, Kiel.

Eggert O. 1927, Die Wendenzüge Waldemars I. und Knuts VI. von Dänemark nach Pommern und Mecklenburg, „Baltische Studien NF“ 29, 1-149.

Eggert O. 1928, Dänish-wendische Kämpfe in Pommern und Mecklenburg (1157-1200), „Baltische Studien NF" 30/2, s. 1-76.

Filipowiak W. 1959, Badania archeologiczno-konserwatorskie w Lubinie, pow. Wolin, „Materiały Zachodniopomorskie" 5, s. 311-330.

Filipowiak W. 1962, Wolinianie. Studium osadnicze, cz. 1. Materiaty, Szczecin.

Filipowiak W. 1997, Wollin (Wolin) und Kammin (Kamień Pomorski) im frühen Mittelalter, w: M. Gläser (red.), Lübecker Kolloquium zur Stadtarchäologie im Hanseraum I: Stand, Aufgaben und Perspektiven, Lübeck, s. 253-265.

Filipowiak W., Konopka M. 2008, The Identity of the Town. Wolin Town-State $-9^{\text {th }}-12^{\text {th }}$ Centuries, "Quaestiones Medii Aevii Novae" 13, s. 243-287.

Gaziński R. 2006, Świna jako droga wodna w średniowieczu, „Przegląd Zachodniopomorski” 21/4, s. 139-146.

Guzikowski K. 2016, Najazdy zbrojne na Szczecin w XII wieku. Przyczyny - przebieg - skutki, w: A. Aksamitowski, R. Gałaj-Dempniak, H. Walczak, A. Wojtaszak (red.), Wojna - Wojsko - Bezpieczeństwo poprzez stulecia i epoki. Studia i materiały, Szczecin, s. 91-100.

Herrmann J., Donat P. (red.) 1979, Corpus archäologischer Quellen zur Frühgeschichte auf dem Gebiet der DDR (7. bis 12. Jahrhundert), 2. Lieferung, Berlin.

Herold J. 1995, Die slawische Besiedlung der Insel Usedom, w: G. Mangelsdorf (red.), Die Insel Usedom in slawisch-frühdeutscher Zeit, Greifswalder Mitteilungen 1, Frankfurt am Main, s. 17-41.

Hofmeister A. 1924, Zur Chronologie und Topographie der 1. Pommernfahrt des Bischofs Otto von Bamberg, „Pommersche Jahrbücher“ 22, s. 3-25.

Holtz A. 1958, Bischof Otto von Bamerg in Warp. Die Burgwälle in Garz auf Usedom und Neuwarp Altstadt, „Baltische Studien NF” 45, s. 27-42.

Kiersnowscy T. \& R. 1959, Wczesnośredniowieczne skarby srebrne z Pomorza. Materiaty, Polskie Skarby Wczesnośredniowieczne. Inwentarze 2, Polskie Badania Archeologiczne 4, Warszawa-Wrocław.

Kiersnowski R. 1950, Legenda Winety. Studium historyczne, Kraków.

Kiersnowski R. 1951, Kamień i Wolin, „Przegląd Zachodni” 9-10, s. 178-225.

Kondracki J. 1998, Geografia regionalna Polski, Warszawa.

Kowalenko W. 1954, Piana, Świna i Dziwna jako szlaki osadniczo-komunikacyjne Słowiańszczyzny battyckiej VIII-XIII w., „Przegląd Zachodni” 1-2, s. 1-90.

Kunkel O. 1932, Burgwallforschung in Pommern, „Pommersche Heimatpflege“ 3/3, s. 81-92.

Kunkel O. 1940, Urgeschichte, Volkskunde, Landesgeschichte und Stadtkultur, kirchliche Kunst, „Baltische Studien” 42, s. 274-342. 
Labuda G. 1988, Wolinianie - plemię pomorskie czy wieleckie?, w: G. Labuda, St. Tabaczyński (red.), Studia nad etnogeneza Stowian i kultura Europy wczesnośredniowiecznej, t. 2, Wrocław-Warszawa-Kraków-Gdańsk-Łódź, s. 65-76.

Leciejewicz L. 1962, Poczatki nadmorskich miast na Pomorzu Zachodnim, Wrocław-Warszawa-Kraków.

Leciejewicz L. 1975, Świna, w: G. Labuda, Z. Stieber (red.), Stownik Starożytności Stowiańskich, t. 5, Wrocław-Warszawa-Kraków-Gdańsk, s. 591-592.

Leciejewicz L. 1983, O rozwoju miast w księstwie zachodniopomorskim na przetomie XII/XIII wieku, w: J. Żak, J. Ostoja-Zagórski red., Studia z dziejów i kultury zachodniej Stowiańszczyzny, Poznań, s. $121-153$.

Łosiński W. 1982, Osadnictwo plemienne Pomorza (VI-X wiek), Wrocław-Warszawa-Kraków-Gdańsk-Łódź.

Malinowski T. 1973, Warunki naturalne wyspy Wolin, w: T. Białecki (red.), Z dziejów ziemi wolińskiej, Szczecin, s. 10-36.

Morawiec J. 2009, Vikings among the Slavs. Jomsborg and the Jomsvikings in Old Norse Tradition, "Studia Medievalia Septentrionalia", t. 17, Wien.

Myśliński K. 1948, Bogusław I, ksiażęe Pomorza Zachodniego, Bydgoszcz-Gdańsk-Szczecin 1948.

Osadczuk A. 1999, Zalew Szczeciński w świetle analizy cech fizjograficznych, w: Problemy geologii, hydrogeologii i ochrony środowiska wybrzeża morskiego Pomorza Zachodniego. Przewodnik LXX Zjazdu Naukowego Polskiego Towarzystwa Geologicznego, Szczecin, s. 215-241.

Piotrowski A. 1999, Etapy rozwoju Bramy Świny, w: Problemy geologii, hydrogeologii i ochrony środowiska wybrzeża morskiego Pomorza Zachodniego. Przewodnik LXX Zjazdu Naukowego Polskiego Towarzystwa Geologicznego, Szczecin, s. 215-241.

Piskorski J.M. 2002, Pomorze plemienne. Historia - Archeologia - Językoznawstwo, Poznań.

Quandt L. 1868, Zur Urgeschichte Pomoranen, "Baltische Studien“" 22, s. 121-213.

Rębkowski M. 2011, Św. Otton a archeologia. O potrzebie i perspektywach badań, w: M. Rębkowski, S. Rosik (red.), Populi terrae marisque. Prace poświęcone pamięci Profesora Lecha Leciejewicza, Wrocław, s. 93-120.

Rębkowski M. 2016, Od grodu książęcego do rezydencji prepozyta kapituly. Lubin w XI-XVI w., „Archaeologia Historica Polona” 24, s. 59-74.

Rębkowski M. red. 2018, Lubin. Early Medieval Stronghold at the Mouth of the Oder River, Szczecin. Rogosz R. 1974, Grodzisko wczesnośredniowieczne w Szczecinie-Mścięcinie, Warszawa.

Rosik S. 2010, Conversio gentis Pomeranorum. Studium świadectwa o wydarzeniu (XII wiek), Wrocław. Rymar E. 1992, Nad Odra czy Odra-Świna? Jeszcze raz w sprawie identyfikacji grodu Gridiz, Gradicia z trasy pierwszej wyprawy misyjnej Ottona bamberskiego na Pomorze, „Przegląd Zachodniopomorski” 7 (36), z. 4, s. 7-27.

Rymar 2005, Rodowód ksiażą pomorskich, Szczecin $2005^{2}$.

Spors J. 1981, Ośrodki stoleczne państwa zachodniopomorskiego w XII i pierwszej połowie XIII wieku, „Materiały Zachodniopomorskie”, t. 27, s. 209-234.

Spors J. 1988, Studia nad wczesnośredniowiecznymi dziejami Pomorza Zachodniego. XII-pierwsza potowa XIII w., Słupsk.

Spors J. 1991, Organizacja kasztelańska na Pomorzu Zachodnim w XII-XIII w., Słupsk.

Sułowski Z. 1952, Najstarsza granica zachodnia Polski, „Przegląd Zachodni” 1952, nr 3-4, s. 343-483.

Szczesiak R. 1995, Beiträge zu den slawischen Burgen und Grabfunden der Insel Usedom sowie zur slawischen Keramik vom Schloßberg und dem Bauhof bei Usedom, w: G. Mangelsdorf (red.), Die Insel Usedom in slawisch-frühdeutscher Zeit, Greifswalder Mitteilungen 1, Frankfurt am Main, s. 43-71.

Ślaski K. 1960, Podzialy terytorialne Pomorza w XII-XIII wieku, Poznań.

Wehner D. 2007, Der frühgeschichtliche Seehandelsplatz Wolin und sein Umland. Eine Studie zu Zentrum und Peripherie, Studien zur Siedlungsgeschichte und Archäologie der Ostseegebiet, t. 8, Neumünster. 